\title{
ANKLE BRACE ATTENUATES THE MEDIAL-LATERAL GROUND REACTION FORCE DURING BASKETBALL REBOUND JUMP
}

\author{
ÓRTESE DE TORNOZELO ATENUA A FORÇA DE REAÇÃO DO SOLO MEDIOLATERAL DURANTESALTO \\ DEREBOTEDOBASQUETEBOL
}

Artigo Original

\section{ORTESIS PARA TOBILLO ATENÚA LA FUERZA DEREACCIÓN DEL SUELO MEDIOLATERAL DURANTE EL SALTO DEREBOTE EN EL BALONCESTO}

\begin{abstract}
Alex Castro ${ }^{1,2}$
(Physical Education Professional)

Márcio Fagundes Goethel²

(Physical Education Professional)

Arthur Fernandes Gáspari ${ }^{1}$

(Physical Education Professional)

Luciano Fernandes Crozara ${ }^{2}$

(Physical Education Professional)

Mauro Gonçalves²

(physiotherapist)

\section{Universidade Estadual de Campinas, Faculdade de Educação Física, Laboratório de Fisiologia do Exercício, Campinas, SP, Brasil. 2. Universidade Estadual Paulista, Departamento de Educação Física, Laboratório de Biomecânica, Rio Claro, SP, Brasil.}

\section{Correspondence:}

Universidade Estadual de Campinas, Faculdade de Educação Física, Laboratório de Fisiologia do Exercício. Av. Érico Veríssimo, Cidade Universitária Zeferino Vaz, Barão Geraldo, Campinas, SP, Brazil. 13083-851. ax.castro@yahoo.com.br

\begin{abstract}
Introduction: The jump landing is the leading cause for ankle injuries in basketball. It has been shown that the use of ankle brace is effective to prevent these injuries by increasing the mechanical stability of the ankle at the initial contact of the foot with the ground. Objective: To investigate the effects of ankle brace on the ground reaction force (GRF) during the simulation of a basketball rebound jump. Method: Eleven young male basketball players randomly carried out a simulated basketball rebound jump under two conditions, with and without ankle brace (lace-up). Dynamic parameters of vertical GRF (take-off and landing vertical peaks, time to take-off and landing vertical peaks, take-off impulse peak, impulse at 50 milliseconds of landing, and jump height) and medial-lateral (take-off and landing medial-lateral peaks, and time to reach medial-lateral peaks at take-off and landing) were recorded by force platform during rebound jumps in each tested condition. The comparisons between the tested conditions were performed by paired $t$ test $(P<0.05)$. Results: The use of ankle braces reduced the medial and lateral peaks of the GRF by $-15.7 \%(P=0.035)$ and $-24.9 \%(P=0.012)$, respectively, during the landing of the rebound jump. Additionally, wearing the brace did not affect any dynamic parameters of vertical GRF or temporal parameters of the medial-lateral GRF $(P>0.05)$. Conclusion: The use of ankle brace during basketball rebound jumps attenuates the magnitude of medial-lateral GRF on the landing phase, without changing the vertical GRF. This finding indicates that the use of brace increases the medial-lateral mechanical protection by decreasing the shear force exerted on the athlete's body without change the application of propulsive forces in the take-off and the impact absorption quality in the landing during the basketball rebound jump.
\end{abstract}

Keywords: sports; ankle/injuries; basketball/injuries.

\section{RESUMO}

Introdução: A aterrissagem do salto é a principal causa de lesões de tornozelo no basquetebol. Demonstrou-se que o uso de órtese de tornozelo é efetivo para prevenir estas lesões, porque aumenta a estabilidade mecânica do tornozelo no contato inicial do pé com o solo. Objetivo: Investigar os efeitos do uso de órtese de tornozelo sobre a força de reação do solo (FRS) durante simulação de um salto de rebote do basquetebol. Método: Onzejovens jogadores de basquetebol do sexo masculino realizaram randomicamente um salto de rebote do basquetebol simulado em duas condições, com e sem órtese de tornozelo (lace-up). Os parâmetros dinâmicos da FRS vertical (picos verticais na decolagem e aterrissagem, tempo até os picos verticais na decolagem e aterrissagem, pico de impulso na decolagem, impulso nos 50 milissegundos da aterrissagem e altura do salto) e mediolateral (picos mediolaterais na decolagem e aterrissagem e tempo para atingir os picos mediolaterais na decolagem e aterrissagem), foram registrados por plataforma de força durante os saltos de rebote em cada condição testada. As comparações entre as condições testadas foram realizadas pelo teste t pareado $(P<0,05)$. Resultados: O uso de órteses de tornozelo reduziu os picos mediais e laterais da FRS em-15,7\% ( $P=0,035)$ e-24,9\% ( $P=0,012)$, respectivamente, durante a aterrissagem do salto de rebote. Além disso, 0 uso da órtese de tornozelo não afetou nenhum parâmetro dinâmico da FRS vertical ou parâmetros temporais da FRS mediolateral $(P>0,05)$. Conclusão: $O$ uso de órtese de tornozelo durante os saltos de rebote do basquetebol atenua a magnitude da FRS mediolateral na fase aterrissagem, sem alterar a FRS vertical. Esse achado indica que o uso de órtese aumenta a proteção mecânica mediolateral pela redução da força de cisalhamento exercida sobre o corpo do atleta, sem alterar a aplicação das forças de propulsão na decolagem e a qualidade de absorção de impacto na aterrissagem durante o salto de rebote do basquetebol.

Descritores: esportes; tornozelo/lesões; basquetebol/lesões.

\section{RESUMEN}

Introducción: El aterrizaje del salto es la principal causa de lesiones de tobillo en el baloncesto. Se ha demostrado que el uso de ortesis para tobillo es eficaz para evitar este tipo de lesiones, ya que aumenta la estabilidad mecánica del tobillo en el contacto inicial del pie con el suelo. Objetivo: Investigar los efectos del uso de ortesis para tobillo sobre la 
fuerza de reacción del suelo (FRS) durante la simulación de un salto de rebote de baloncesto. Métodos: Oncejóvenes del sexo masculino, jugadores de baloncesto, fueron sometidos al azar a un salto de rebote simulado de baloncesto en dos condiciones, con y sin ortesis para tobillo (lace-up). Los parámetros dinámicos de la FRS vertical (picos verticales en el despegue y aterrizaje, tiempo hasta el pico vertical en el despegue y el aterrizaje, el empuje de pico en el despegue, el empuje en 50 milisegundos de aterrizaje y altura del salto) y mediolateral (picos mediolaterales en el despegue yel aterrizaje y el tiempo para alcanzar el pico mediolateral en el despegue y el aterrizaje) fueron registrados por la plataforma de fuerza durante el salto de rebote. Las comparaciones entre las condiciones estudiadas se realizaron mediante la prueba t pareada $(P<0,05)$. Resultados: El uso de la ortesis para tobillo redujo los picos mediales y laterales de la FRS en $-15,7 \%(P=0,035)$ y-24,9\% ( $P=0,012)$, respectivamente, durante el aterrizaje del salto rebote. Además, el uso de ortesis para tobillo no afectó a ningún parámetro dinámico de la FRS vertical o parámetros temporales de la FRS mediolateral $(P>0,05)$. Conclusión: El uso de ortesis para tobillo para el salto de rebote de baloncesto atenúa la magnitud de la FRS mediolateral en el fase de aterrizaje sin cambiar el FRS vertical. Este hallazgo indica que el uso de la ortesis aumenta la protección mecánica mediolateral al reducir la fuerza de corte ejercida sobre el cuerpo del atleta, sin cambiar la aplicación de las fuerzas de propulsión en el despegue y la calidad de absorción de impactos en el aterrizaje del salto durante el rebote en el baloncesto.

Descriptores: deportes; tobillo/lesiones; baloncesto/lesiones.

\section{INTRODUCTION}

The jump is a fundamental skill for success in basketball ${ }^{1}$. During a game, each athlete completes between 40-49 jumps ${ }^{2}$. The high frequency of these movements throughout the game makes the jump a risk factor associated with injuries in the lower limbs; this risk increases especially when the athlete loses visual contact with the ground, such as in a shot or in a jump for a rebound ${ }^{3}$.

Recent studies show that ankle injuries are approximately $50 \%$ of the reasons for being placed on the injury reserve list for a week or more, and the landing of a jump is the main reason (45\%) for these lesions $\mathrm{s}^{3,4}$. It is important to highlight that sprains represent $90 \%$ of all ankle injuries in basketball players, and in these, the lateral ligament structure is most frequently compromised ${ }^{5}$. In order to minimize the seriousness and frequency of these injuries, studies have suggested the use of ankle brace as a preventative measure. In basketball, specifically, such an intervention can reduce the occurrence of acute ankle injuries up to $66 \%$.

One of the primary mechanisms responsible for the prevention of ankle sprains through the use of an ankle brace consists of its ability to restrict the speed and amplitude of inversion and eversion movements of the ankle at the foot's initial contact with the ground ${ }^{7,8}$. By controlling these movements, the ankle remains in a neutral position in the frontal plane; therefore minimizing the exposure of the ligaments of this articulation to forceful external impact in the moment of contact with the ground ${ }^{3,8}$. However, it has been shown that the biomechanical alterations resulting from the use of ankle brace can be beneficial, or even negative ${ }^{9-12}$.

In relation to the ability to land, studies performed by Riemann et al. ${ }^{13}$ and Cordova et al. ${ }^{9}$ demonstrated that the use of the ankle brace reduces the time to reach the peak of vertical impact of the ground reaction force (GRF) during the drop landing. While Distefano et al. ${ }^{7}$ did not show any alterations in jump landing task. Regarding the countermovement jump, the studies of Rosenbaum et al. ${ }^{14}$ and Ozer et al. ${ }^{15}$ showed a reduction in the height of a jump with the use of an ankle brace; in contradiction, the studies of Abián-Vicén et al. ${ }^{16}$ and Dos Anjos et al. ${ }^{17}$ showed no effect at all of the use of ankle brace upon the vertical jump. On the other hand, Sacco et al. ${ }^{12}$ identified a protective effect of the use of an ankle brace (Aircast) during the jump take-off phase, evidenced by the decreasing of the mediolateral GRF. However, this same study did not find changes on GRF during the jump landing phase.

In light of these evidences, it has been shown that the use of ankle brace is effective to prevent ankle injuries in basketball ${ }^{6}$, however the effect of ankle brace upon biomechanics variables of the jump are inconclusive. Additionally, the analysis of mechanical loads during more specific tasks, as simulated rebound jump, enhances the ecological validity of the research ${ }^{1}$ resulting in a more realistic assessment. This approach can brings a clearly explanation to the effects of the use ankle bracing in basketball specific tasks as demonstrated by Shaw et al. ${ }^{11}$ that showed better anterior-posterior dynamic stabilization with the use of lace-up ankle brace during the landing from specific volleyball jumps and Cloak et al. ${ }^{18}$ that found the reduction of the mediolateral GRF with the use of brace in cutting maneuvers.

Thus, the objective of this study is to analyze the effects of a lace-up ankle brace on GRF in male basketball athletes during simulation of a basketball rebound jump. We hypothesized that the use of this brace would offer protection through the reduction of GRF during the simulation of a rebound jump. This data will contribute to greater understanding for designers, coaches, physiotherapists and physicians about the use of ankle brace for basketball players.

\section{METHODS}

Eleven male younger basketball players (age: $17.1 \pm 0.1$ years; height: $183.3 \pm 8.7 \mathrm{~cm}$; body mass: $75.6 \pm 9.0 \mathrm{~kg}$; body fat: $9.4 \pm 4.2 \%$ ) participated in this study. They had at least five years of training experience and were competing in collegiate and regional basketball competitions. Athletes were free from ankle instability and ankle and foot injuries within the previous 12 months at the time of the tests. The study was approved by the local Ethics in Research Committee (Protocol Number: 5123); all the participants were informed about the experimental procedures and signed a consent form.

The participants came to the laboratory for three days, separated by 48-72 hours. On the first day, the ankle anterior drawer test and the talar tilt test were done by an experienced physiotherapist, in order to verify the mechanical instability of the athletes'ankles ${ }^{19}$. The athletes were also evaluated for functional ankle instability using the Brazilian-Portuguese version of Cumberland Ankle Instability Tool (CAIT ${ }^{20}$. Individuals with negative results on the ankle anterior drawer test and the talar tilt test ${ }^{19}$ and scores above 24 on the CAIT, on a scale of 0-30 points for the left and right ankle were included in the study ${ }^{20}$.

Subsequently, the athletes performed a test of vertical jump to determine the maximum vertical reach of the athlete and were familiarized until they had obtained the motor skills to perform the movement 
required in this study. This test began with the participant in an orthostatic position. From this stationary position, the athletes were instructed to jumping with two footed, as high as possible. The swinging of the arms and downward countermovement were permitted, and the athlete was requested to touch with his fingertips the highest point possible on a vertical metric scale positioned next to athlete. The participants performed three jumps with 30 seconds intervals, and the highest reach was recorded ${ }^{21}$. This test has an excellent intra-test reliability (intraclass correlation coefficient $-I C C=0.96)^{22}$.

On the second and third day the rebound simulation jumps were evaluated with and without the use of ankle brace on both ankles; these evaluations were counterbalanced and in random order. Initially, the participants performed warm-ups on a cycle ergometer (Cefise ${ }^{\circledR}$, Nova Odessa, BRA) for five minutes. Afterwards, the athletes performed vertical jumps simulating a basketball rebound jump on a force platform. The subjects took-off from an orthostatic position, with the arms extended alongside the body. The jump was performed after a downward countermovement, using both arms and legs to assist in projecting the body upwards. They were instructed to touch their hands to a basketball suspended at $95 \%$ of the maximum reach of each athlete, as measured during the test of vertical jump. The ball was positioned $5 \mathrm{~cm}$ in front of the center of the force platform in order to provide visual contact with the ball during the execution of the jumps. The knee angle during the countermovement was not controlled to ensure a more realistic simulation of the rebound jump in basketball. Three trials were recorded, both with and without brace, with 30 s intervals between each jump to minimize fatigue effects ${ }^{7,11}$. Each participant wore their own basketball shoes (the same pair was used for all trials) ${ }^{7}$ and all exhibited appropriate skill levels to perform the test.

The ankle brace tested was the lace-up kind (Horse Jump ${ }^{\circledR}$, Franca, Brazil) and it was chosen because it is low-cost, comfortable, easy to apply, reduce ankle injuries and be frequently used by basketball athletes ${ }^{6,14}$. This brace is made of flexible material, with laces and two semi-rigid rods on the sides, which cross the dorsal and ventral surfaces of the foot, wrapping the ankle in a figure eight. The semi-rigid rods are laterally fixed to the leg in the shape of a " $U$ ", using velcro strips, passing through the lateral and medial malleolus (Figure 1).

The measurements of GRF were obtained during each one of the rebound jumps through a force platform (AMTI ${ }^{\circledR}$, OR6-6, Watertown), operating at a frequency of $2000 \mathrm{~Hz}_{1}^{23}$ with 4000 times gain and a 12 bit A/D converter. Prior to each testing session, the force platform was

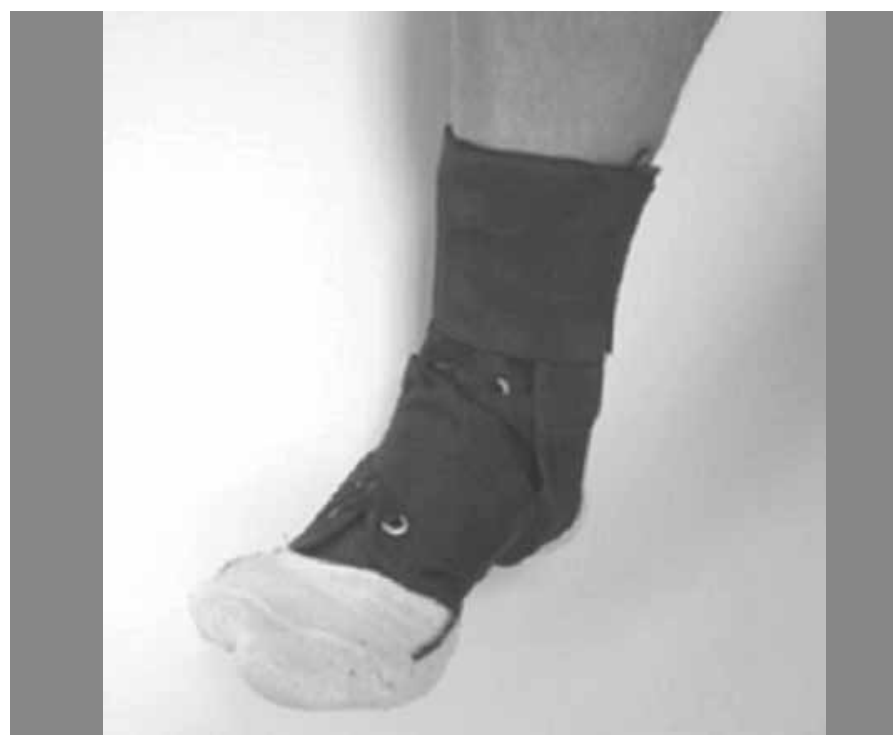

Figure 1. Ankle brace. calibrated in accordance with manufacturer guidelines. The data was filtered using a digital filter low pass Butterworth of $4^{\text {th }}$ order, at $95 \mathrm{~Hz}$, based on residual analyzis ${ }^{24}$. The GRF measurements were normalized by the body weight and the final values were considered as the average of the last two attempts of the rebound jump for each condition that was tested.

For the vertical component of the GRF (Fz) we analyzed peak vertical force upon take-off and landing, the time to the peak vertical force at take-off and landing 10,12, impulse peak upon take-off calculated from the area under the curve GRF $x$ time, and impulse in the first 50 ms of landing as a parameter indicating the external load applied to the lower limbs during a critical moment $\mathrm{t}^{1,10}$ and height of the jump by time of flight $^{25,26}$. For the mediolateral component of the GRF (Fx) we considered the greatest medial and lateral peaks during the take-off and the landing phases ${ }^{12}$ and time to the peak medial force and lateral force at take-off and landing phases.

\section{Statistical analysis}

After verify data distribution (Shapiro-Wilk test), the comparison of the dependent variable between the conditions with and without brace were performed by Paired t test. The statistical analyses were performed through SPSS-18.0 software (SPSS Inc., Chicago, IL, USA); $5 \%(P<0.05)$ was considered a significant level of difference. The sample size was calculated using $G^{*}$ Power based on data of pilot study for mediolateral GRF, assuming a bi-directional alpha of 0.05 , a statistical power of $80 \%(1-\beta=0.80)$ and considering the design of the present study for pared samples.

\section{RESULTS}

Significant differences were identified among the conditions tested for the medial and lateral peaks of GRF during landing jump phase. The use of ankle brace caused reduction of $-15.7 \%(P=0.035)$ in the medial force and of $-24.9 \%(P=0.012)$ in the lateral force during the landing phase of the rebound jump (Figure 2). There were no significant defferences for any dynamical parameters of vertical GRF during take-off and landing jump phases (Figure 3), or for any temporal parameters (time to take-off and landing mediolateral peaks) of mediolateral GRF (Figure 2) during take-off and landing jump phases ( $P>0.05$ ).

\section{DISCUSSION}

Our study shows that the use of lace-up ankle brace attenuates the peaks of mediolateral GRF without altering the vertical GRF during the landing phase of simulated basketball rebound jump. These findings confirm the initial hypothesis of the present study, since the use of a brace attenuates the external load applied to the athlete's body specifically during the landing of the jump when injuries are more common, mainly, ankle injuries.

Our findings of a protocol with great ecological validity corroborate the research of Sacco et al. ${ }^{12}$ and Cloak et al. ${ }^{18}$, who found the reduction of the mediolateral GRF with the use of brace in the take-off of the vertical jump and in the phase of impact of cutting maneuvers, respectively. This set of findings are of great importance since studies have shown that the passive resistance offered by the use of brace promotes the reduction of the speed and amplitude of the inversion and eversion movements of the ankle during jumps and rapid cutting maneuvers, attenuating the external forces that cause the injury of the ankle $8,9,21,27$.

With regard to the landing, we observed that the use of brace attenuated the mediolateral GRF, demonstrating a protective effect in relation to the external load during the landing phase. This result has an interesting implication for the prevention of stress injuries in healthy athletes, since these injuries can be related to continuous exposure to excessive external loads ${ }^{1,28}$. 


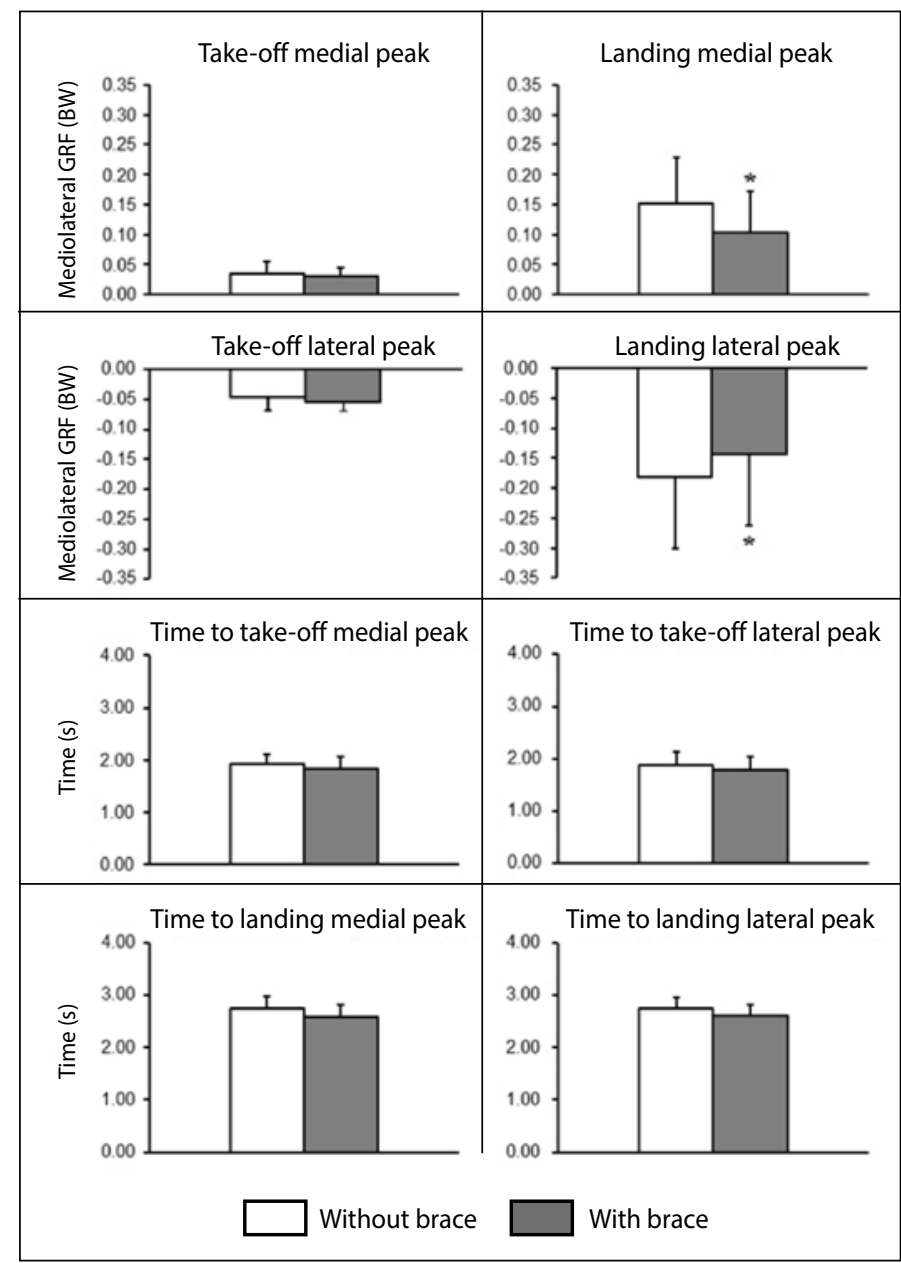

Figure 2. Mediolateral ground reaction force, with and without ankle brace. Data are mean \pm SD. * denote $P<0.05$ vs. without ankle brace. BW = Body Weight.

In this sense, considering that a body mechanically is in equilibrium when the sum of all forces and moments of force acting on it is zero ${ }^{29}$, the reducing of magnitude of the mediolateral GRF indicates that this body is more balanced on the axis in which this force was applied. Thus resulting in a system (body) more stable during takeoff and landing of rebound jump with less external forces (shear forces) applied on the lower limb, including the feet and ankles that are in contact with the ground $^{30}$. Interestingly these results did not affect the temporal parameters of mediolateral GRF. This finding indicates that the time required for the absorption of shear forces was not altered by use of the brace.

Additionally, our results showed only non-significant results for the vertical GRF in the rebound jump with ankle brace. These findings are supported by the studies of Sacco et al. ${ }^{12}$ and DiStefano et al. ${ }^{7}$, which attribute the consistency of the vertical GRF among the conditions tested as being consequences of the increase in the angle of knee flexion upon initial contact with the ground, due to the use of the ankle brace, which restricts the amplitude of the dorsiflexion and plantar flexion of the ankle. However, despite the similarity of our findings with the studies of Sacco et al. ${ }^{12}$ and DiStefano et al. , the present investigation has great ecological validity what bear a closer resemblance to the demands of basketball jumps?

In view of the fact that the use of lace-up brace reduce the incidence of ankle injuries for basketball athletes ${ }^{6}$, the reduction of mediolateral GRF without change in the vertical component can constitute one of the mechanisms by which these brace prevent injuries in lower limb of healthy athletes. Thus, the use the brace could be recommended to increase the stability and mechanical protection mediolateral of the body during the rebound jump in basketball players, without compromising

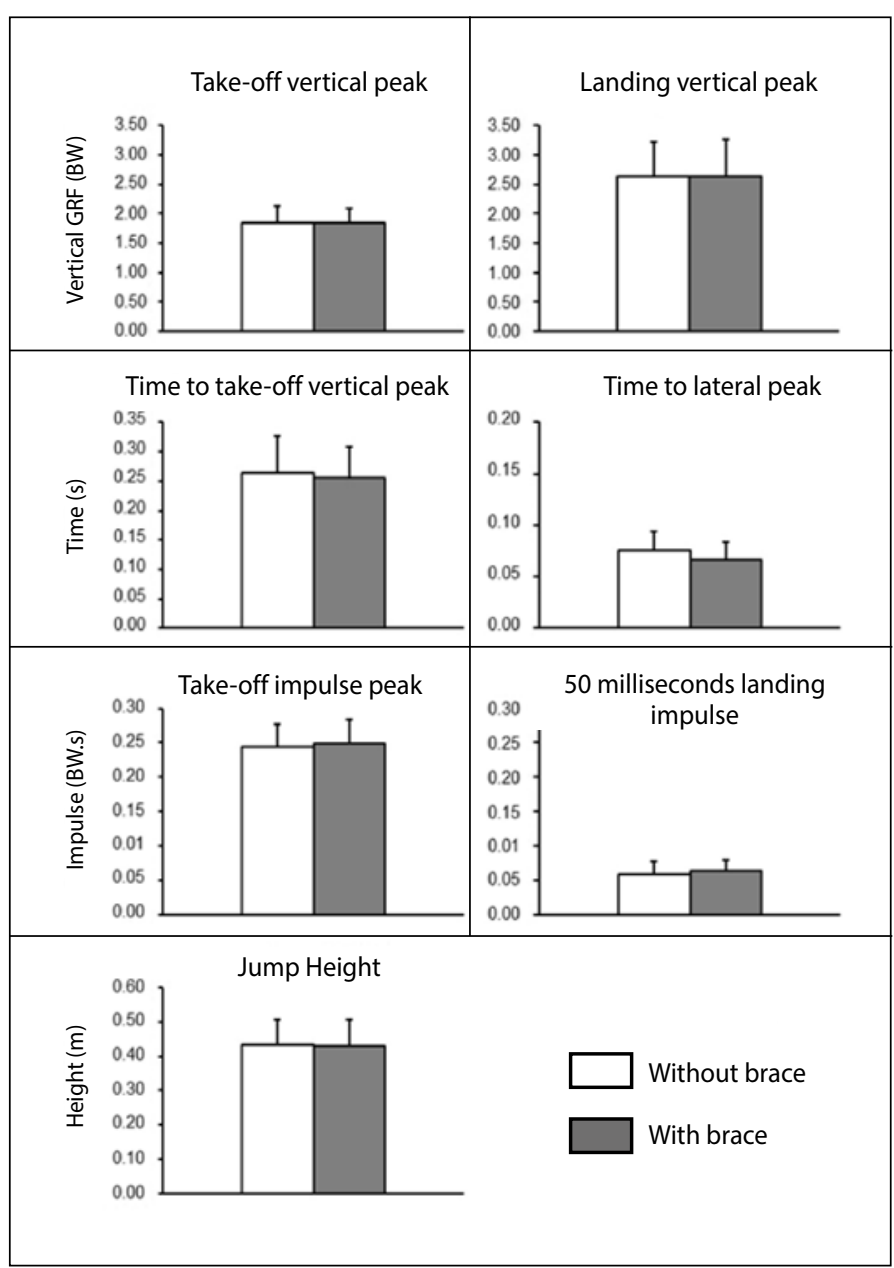

Figure 3. Vertical ground reaction force, with and without ankle brace. Data are mean \pm SD. BW $=$ Body Weight.

jump performance and the absorbing of impact forces. These assumptions supports coaches, physiotherapists and physicians who advocate the use of ankle bracing (lace-up) for healthy basketball players.

At last, although the results of present study are encouraging, some limitations must be considered. This study was limited to male younger basketball players and future investigations on larger and more diverse populations may be required. In addition, this study examined the immediate effects of the use of ankle bracing. Accordingly, the length of time that the brace offers the protection measured during the basketball game and effectiveness of bracing over prolonged use is not well known. Finally, in our study the rebound jumps were performed in controlled conditions by jump height. It was necessary to guarantee that the alterations observed in the GRF were, in fact, due to the use of the brace, and not due to possible variations in the height of the jump. In spite of these limitations, the ecological validity of this study should be highlighted, for it tested the effects of the use of the brace in the vertical jump under conditions that are most similar to those of the sport (rebound jump) and not yet reported in literature.

\section{CONCLUSION}

In conclusion, the use of lace-up ankle brace in simulated basketball rebound jump attenuated the magnitude of mediolateral GRF during landing jump phase, without altering the vertical GRF. This indicates that the use of brace increase mediolateral mechanical protection, decreasing the shear force exerted on the athlete's body without change the absorbing quality of impact forces and application of propulsive forces during the rebound jump in basketball. It is suggested to increase the 
mediolateral stability of the body during landing jump and reduce the risk of lower limb's injuries, especially in the feet and ankles, in healthy young basketball players.

\section{ACKNOWLEDGEMENTS}

The authors wish to thanks the funding providing by São Paulo Research Foundation (Process: 2011/15980-5; 2010/10886-8) and National Counsel of Technological and Scientific Development (Process: 482418/2009-5). The results of the current study do not constitute endorsement of the product by the authors or the NSCA.

All authors declare no potential conflict of interest related to this article.

AUTHORS' CONTRIBUTIONS: Each author contributed individually and significantly to the development of the manuscript. AC (0000-0002-0298-2672)* designed the study and was responsible for data collection, data analysis and interpretation, and the writing of the manuscript. MFG (0000-0003-4481-9512)* helped data collection, data analysis and interpretation, and manuscript review. AFG (0000-0002-4020-2892)* helped in data analysis and interpretation and manuscript review. LFC (0000-0002-3534-5565)* helped data collection and manuscript review. MG (0000-0002-4087-1113) supervised the data collection, analysis, and supervised the writing of the manuscript. All authors read and approved the final manuscript. *ORCID (Open Researcher and Contributor ID).

\section{REFERENCES}

1. Acquesta FM, Peneireiro GM, Bianco $R$, Amadio AC, Júlio CS. Dynamical characteristics of basketball specific movements. Rev Port Ciên Desp. 2007;7(2):174-82

2. Ben Abdelkrim N, El Fazaa S, El Ati J. Time-motion analysis and physiological data of elite under-19-year-old basketball players during competition. Br J Sports Med. 2007;41(2):69-75.

3. McKay GD, Goldie PA, Payne WR, Oakes BW. Ankle injuries in basketball: injury rate and risk factors. $\mathrm{Br}$ J Sports Med. 2001;35(2):103-8.

4. McCarthy MM, Voos JE, Nguyen JT, Callahan L, Hannafin JA. Injury profile in elite female basketball athletes at the Womens National Basketball Association combine. Am J Sports Med. 2013;41(3):645-51.

5. Fong DT, Hong Y, Chan LK, Yung PS, Chan KM. A systematic review on ankle injury and ankle sprain in sports. Sports Med. 2007;37(1):73-94.

6. McGuine TA, Brooks A, Hetzel S. The effect of lace-up ankle braces on injury rates in high school basketball players. Am J Sports Med. 2011;39(9):1840-8.

7. DiStefano $L$, Padua DA, Brown CN, Guskiewicz KM. Lower extremity kinematics and ground reaction forces after prophylactic lace-up ankle bracing. J Athl Train. 2008;43(3):234-41.

8. Zhang S, Wortley M, Chen Q, Freedman J. Efficacy of an ankle brace with a subtalar locking system in inversion control in dynamic movements. J Orthop Sports Phys Ther. 2009;39(12):875-83.

9. Cordova ML, Takahashi Y, Kress GM, Brucker JB, Finch AE. Influence of external ankle support on lower extremity joint mechanics during drop landings. J Sport Rehabil. 2010;19(2):136-48.

10. Sacco Ide C, Takahasi HY, Suda EY, Battistella LR, Kavamoto CA, Lopes JA, et al. Ground reaction force in basketball cutting maneuvers with and without ankle bracing and taping. Sao Paulo Med J. 2006;124(5):245-52

11. Shaw MY, Gribble PA, Frye JL. Ankle bracing, fatigue, and time to stabilization in collegiate volleyball athletes. J Athl Train. 2008:43(2):164-71.

12. Sacco ICN, Takahasi HY, Vasconcellos, AA, Suda EY, Bacarin TA, Pereira CS, et al. Influence of ankle devices in the jump and landing biomechanical responses in basketball. Rev Bras Med Esporte. 2004;10(4):447-52.

13. Riemann BL, Schmitz RJ, Gale M, McCaw ST. Effect of ankle taping and bracing on vertical ground reaction forces during drop landings before and after treadmill jogging. J Orthop Sports Phys Ther. 2002;32(12):628-35

14. Rosenbaum D, Kamps N, Bosch K, Thorwesten L, Völker K, Eils E. The influence of external ankle braces on subjective and objective parameters of performance in a sports-related agility course. Knee Surg Sports Traumatol Arthrosc. 2005;13(5):419-25.

15. Ozer D, Senbursa G, Baltaci G, Hayran M. The effect on neuromuscular stability, performance, multi-joint coordination and proprioception of barefoot, taping or preventative bracing. Foot (Edinb). 2009;19(4):205-10

16. Abián-Vicén J, Alegre LM, Fernández-Rodríguez JM, Lara AJ, Meana M, Aguado X. Ankle taping does not impair performance in jump or balance tests. J Sports Sci Med. 2008;7(3):350-6.

17. Dos Anjos MTS, Brasil LJ, Barros BO, Bastos NCS, Moraes GFS. Efeito do Uso do Estabilizador Active Ankle System ${ }^{\oplus}$ na Altura do Salto Vertical em Jogadores de Voleibol. Rev Bras Med Esporte. 2009;15(5):347-50

18. Cloak R, Galloway S, Wyon M. The effect of ankle bracing on peak mediolateral ground reaction force during cutting maneuvers in collegiate male basketball players. J Strength Cond Res. 2010;24(9):2429-33

19. Dubin JC, Comeau D, McClelland RI, Dubin RA, Ferrel E. Lateral and syndesmotic ankle sprain injuries: a narrative literature review. J Chiropr Med. 2011;10(3):204-19.

20. De Noronha M, Refshauge KM, Kilbreath SL, Figueiredo VG. Cross-cultural adaptation of the BrazilianPortuguese version of the Cumberland Ankle Instability Tool (CAIT). Disabil Rehabil. 2008;30(26):1959-65.

21. Delextrat A, Cohen D. Physiological testing of basketball players: toward a standard evaluation of anaerobic fitness. J Strength Cond Res. 2008;22(4):1066-72.

22. Hopkins WG. Analysis of reliability with a spreadsheet (beta version) [accessed on 2015 Jan 20]. Disponível em: www.sportsci.org/resource/stats/xrely.xIs2012.

23. Roesler CRM, Iturrioz I. Identificação do conteúdo de freqüências presente na força de reação do solo medida com plataforma de forças. Rev Bras Biomec. 2002;3(4):51-6.

24. Winter DA . Biomechanics and motor control of human movement. 2nd ed. Waterloo: Wiley-Interscience Publication; 1990.

25. Markovic G, Dizdar D, Jukic I, Cardinale M. Reliability and factorial validity of squat and countermovement jump tests. J Strength Cond Res. 2004;18(3):551-5.

26. Dias JA, Dal Pupo J, Reis DC, Borges L, Santos SG, Moro AR, Borges NG Jr. Validity of two methods for estimation of vertical jump height. J Strength Cond Res. 2011;25(7):2034-9.

27. Cordova ML, Ingersoll CD, Palmieri RM. Efficacy of prophylactic ankle support: an experimental perspective J Athl Train. 2002;37(4):446-57.

28. Azevedo AP, Brandina K, Bianco R, Oliveira VH, Souza JR, Mezencio B, et al. Effects of replica running shoes upon external forces and muscle activity during running. J Sports Sci. 2012;30(9):929-35.

29. Duarte M, Freitas SM. Revision of posturography based on force plate for balance evaluation. Rev Bras Fisioter. 2010;14(3):183-92

30. Hamill J, Knutzen KM, Bates BT, Kirkpatrick G. Evaluation of two ankle appliances using ground reaction force data. J Orthop Sports Phys Ther. 1986;7(5):244-9. 